\title{
EXPERIMENTAL TESTING OF COMPOSITE SANDWICH PANELS WITH DIFFERENT FACE SHEETS
}

\author{
Ana Trombeva-Gavriloska* \\ Faculty of Architecture, Ss. Cyril and Methodius University in Skopje, Republic of Macedonia \\ Marijana Lazarevska \\ Faculty of Civil Engineering, Ss. Cyril and Methodius University in Skopje, Republic of \\ Macedonia \\ Meri Cvetkovska \\ Faculty of Civil Engineering, Ss. Cyril and Methodius University in Skopje, Republic of \\ Macedonia
}

An experimental tests performed on two series of sandwich panels, differed by the type of the matrix used for the composite face sheets, are presented in this paper. By applying a linear load in the middle of the span, these sandwich panels were subjected on three points bending test. The analysis was performed in order to evaluate the influence of the matrix type on the ultimate mechanical characteristics of the sandwich panels. By analyzing the $F-\delta$ behavior of the sandwich panels, as well as the F- $\sigma$ behavior of the composite face sheets, the influence of the matrix type used in the composite face sheets has been evaluated.

Key words: Composite sandwich panels, Mechanical properties, Experimental testing

\section{INTRODUCTION}

Sandwich elements are being often used as constructive elements in civil engineering structures. The usage is mostly based on their high performance, such as high stiffness and high strength, in comparison with their weight. Based on the concept of increasing the bending bearing capacity and stiffness, sandwich panels are defined as structures that have low weight. They are multi layered composites formed of two thick, but strong and stiff face sheets, and weak core. Depending on the specific application of the final product, different materials could be used for fabrication of sandwich panels.

Any constructive product available as a thin plate could be used for the face sheets [02]. Materials are chosen so that face sheets will have high bending stiffness, high tensile and compressive strength and excellent resistance to external influences. Composite materials, as anisotropic materials, especially as materials with high strength to weight ratio, high stiffness to weight ratio and as non-corrosiveness easy handling material that offer many options in the design process, are very often used as materials for the face sheets.
Lingaiah and Suryanarayana [05] in their work present experimental research of sandwich panels with composite face sheets and aluminum honeycomb core subjected on bending, while the Alias [1] did experiments on sandwich panel with steel face sheets and polyvinylchloride core statically loaded with concentrated force.

The fracture mechanism should be well-known in order to determine the mechanical characteristics of sandwich panels. Fracture types of sandwich panels in linear part of the behavior, are studied and discussed by Allen [02], Ashby and Gibson [03] and Plantema [08]. In order to simplify the mathematical operations numerous analyses of sandwich panels are being performed on beam models. Swanson and Kim [9] and Mines and Alias [07], were focused on analyses of sandwich beam fracture. Fracture of the sandwich elements could occur as a result of reaching the ultimate compressive or tensile strength of the face sheets or as a result of reaching the ultimate shear strength of the core [6, 4]. According to the available literature the mechanical characteristics and the fracture type of the sandwich panels depend on the materials used for construction. Mechanical characteristics of sandwich panels 
with composite face sheets depend also on the components used for the composite material.

This paper presents an experimental tests performed on two series of sandwich panels with composite face sheets, differed by the type of the matrix used for the face sheets. Two types of matrix materials, polyester and epoxy based resins, are used for this experiment. Sandwich panels were subjected on three points bending test. The analysis was performed in order to evaluate the influence of the matrix type on the ultimate mechanical characteristics of the sandwich panels. Influence of the matrix type used in the composite face sheets was evaluated by analysis of $F-\delta$ behavior of the series of sandwich panels, as well as by analysis of $F-\sigma$ behavior of the composite face sheets.

\section{PROPERTIES OF SANDWICH PANELS AND TEST SET UP COMPONENTS OF SANDWICH PANELS}

For the purpose of the experimental testing two different series of sandwich panels have been fabricated. The examined sandwich panels were fabricated of polyurethane core and thin composite face sheets. The core of sandwich panels was $60 \mathrm{~mm}$ hard foam polyurethane with density of $30 \mathrm{~kg} / \mathrm{m} 3$. Actually, the sandwich panels' series differ by the type of matrix used for the thin composite face sheets. The thin composite face sheets were fabricated using two types of matrix and fiber glass reinforcement, rowing with density $0,535 \mathrm{~kg} / \mathrm{m} 2$, in two plies. The materials used for production of the sandwich panels are summarized in Table 1.

Table 1: Components of series of tested sandwich panels

\begin{tabular}{|c|c|c|c|c|}
\hline \multirow{2}{*}{$\begin{array}{c}\text { Sandwich } \\
\text { panels }\end{array}$} & Core & \multicolumn{3}{|c|}{ Face sheet } \\
\cline { 3 - 5 } & Matrix & Reinforcement plies & Reinforcement \\
\hline \hline SP2R & Polyurethane & Polyester resin & 2 & Rowing \\
\hline SE2R & Polyurethane & Epoxy resin & 2 & Rowing \\
\hline
\end{tabular}

The sandwich panels were marked in accordance to the components used for the production of composites face sheets: the first symbol refers to the sandwich panel (S), the second symbol refers to the type of the matrix ( $P$ or $E$ ), the third symbol refers to the number of reinforcement plies (2) and the last fourth symbol (R) denotes the type of the applied reinforcement.

\section{SPECIMEN GEOMETRY}

Test specimens were fabricated by hand lay-up of the composite face sheets on the hard foam polyurethane. Their geometry was defined by the properties of the test machine, Figure 1. All test specimens had a constant length of $1000 \mathrm{~mm}$ and rectangular cross section with width of 300 $\mathrm{mm}$. The depth of each sandwich panel differs depending on the depth of the composite face sheets. For precise determination of the relative strain of each composite face sheet of the tested sandwich panel, strain gages in longitudinal direction were used.

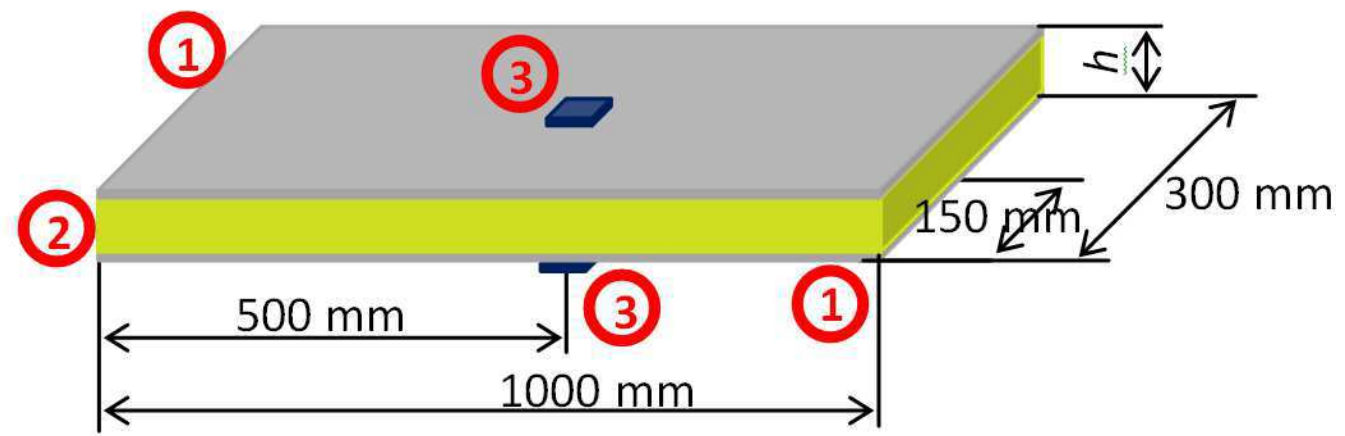

Figure 1: Geometry of sandwich panel specimens 1) composite face sheets; 2) core;

3) strain gages 


\section{EXPERIMENT TEST SETUP}

The final surface preparation was carefully examined for each test specimen prior to the flexural tests. The dimensions of the specimens were measured before the flexural test. In order to record the average area of the specimens, their area was measured at three places.

Experiments were performed by the testing machine SCHENCK HYDROPLUS-PSB, with capacity of $250 \mathrm{kN}$. Tests were made in range up to $25 \mathrm{kN}$. The tests specimens were subjected on three point bending test. Additional device was set on the test machine in order to test the flat beams loaded on flexure. The specimens were carried by steel supports with $50 \mathrm{~mm}$ width set on $50 \mathrm{~mm}$ diameter steel cylinders which permit slip and deformation of the sandwich panels during the experiments. Slip on the contact surface was avoided by using of $2 \mathrm{~mm}$ neoprene layers between sandwich panels and the steel support. Line load was applied through $100 \mathrm{~mm}$ width steel beam mounted on steel cylinder with diameter of $50 \mathrm{~mm}$. A $40 \mathrm{~mm}$ square hole was made in the middle of the steel beam in order to set a strain gage on the top face sheet of the sandwich panel in the middle of the span. By plac- ing a $4 \mathrm{~mm}$ thick neoprene layer between steel beam and sandwich panel the local fracture of the top layers of the composite face sheet was avoided. The actual span of the sandwich beam was $800 \mathrm{~mm}$ and the load was applied with constant speed of $5 \mathrm{~mm} / \mathrm{min}$.

Flexural force was determined with force transducer integrated in the testing machine. The full bridge strain gage type force transducer was used. Head displacement of the testing machine was determined by displacement transducer of inductive type. Strain data were determinate using strain gage in longitudinal direction. The strain gage with resistant of 350 , type HBM 10/350LY11 were selected in order to reduce the heating effects due to the low conductivity of the used composite materials. The surface preparation and the selection of bonding agent for the strain gage installation was done in consultation with the strain gage producer. The temperature compensation was done by a passive strain gage, connected in half-bridge. The force versus head displacement and the force versus strain were continuously recorded with sampling rate of $50 \mathrm{~Hz}$. The HBM Spider 8 and software HBM CATMAN 4.0 were used for data acquisition.

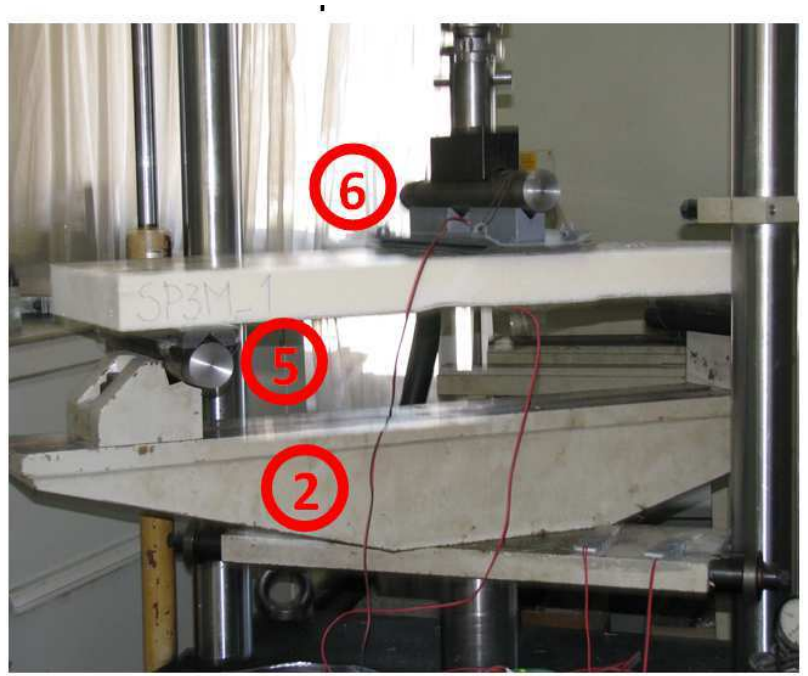

Figure 2: Testing machine and equipment for flexural test of sandwich specimens: 1) testing machine; 2) additional device for testing flat beams; 3) acquisition unit; 4) computer; 5) steel support lay on cylinder; 6) loading steel beam on cylinder

\section{EXPERIMENTALLY OBTAINED RESULTS AND DISCUSSION}

The flexural testing has been performed on two different series of specimens. Two specimens of each serial were tested for the purpose of the ex- periment. The geometry and the experimentally obtained results for tested sandwich specimens are summarized in the Table 2. 
Table 2: Geometrical and mechanical properties of tested sandwich specimens

\begin{tabular}{|l|c|c|c|c|c|}
\hline $\begin{array}{l}\text { Sandwich } \\
\text { specimen }\end{array}$ & $\begin{array}{c}\text { Face sheet } \\
\text { thickness, } \mathrm{t} \\
{[\mathrm{mm}]}\end{array}$ & $\begin{array}{c}\text { Sandwich panel } \\
\text { thickness, } \mathrm{h} \\
{[\mathrm{mm}]}\end{array}$ & $\begin{array}{c}\text { Load } \\
{[\mathrm{N}]}\end{array}$ & $\begin{array}{c}\text { Deflection } \\
{[\mathrm{mm}]}\end{array}$ & $\begin{array}{c}\text { Tensile } \\
\text { strength } \\
{[\mathrm{MPa}]}\end{array}$ \\
\hline SP2R_1 & 1,5 & 62 & 3340 & 30,67 & 34,65 \\
\hline SP2R_2 & 1,7 & 63 & 3367 & 29,08 & 29,18 \\
\hline SE2R_1 & 1,3 & 62 & 3538 & 32,27 & 41,48 \\
\hline SE2R_2 & 1,2 & 63 & 3511 & 32,58 & 45,07 \\
\hline
\end{tabular}

From the performed tests can be concluded that the behavior of the tested sandwich panels subjected on three points bending test can be divided in three characteristic parts. Behavior of the sandwich panels is linear up to the point where cracking of the polyurethane foam occurs reducing their stiffness. In the nonlinear part, by in- creasing the load, new micro cracks appear and spread through the depth of the core, while the composite face sheets are still in elastic part caring out the applied load. In the last stage crash of the top composite face sheet and core occur followed by a considerable drop in the stiffness of the sandwich panels.

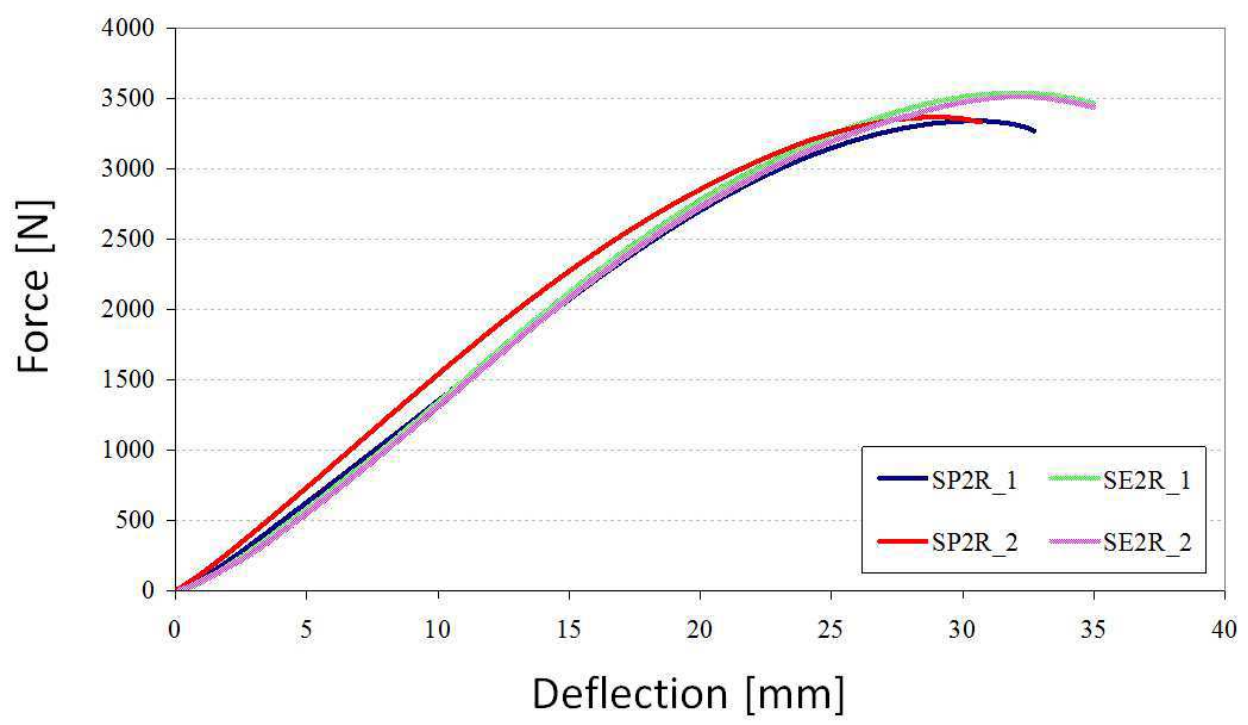

Figure 3. F- $\delta$ diagrams for specimens $S P 2 R$ and SE2R subjected on three point bending test

The $F-\delta$ behavior of the tested sandwich panels SP2R and SE2R in the middle of the span is similar, as can be concluded from the Figure 3. The ultimate strength of the series sandwich panels SE2R is minimally higher in comparison to the series of sandwich panels SP2R. In particular, the behavior of the both series of sandwich panels is in the linear part with the approximately equal stiffness and minor differences observed in the ultimate deformations.

In order to observe the influence of the used matrix on the mechanical properties of the sandwich panels, comparative analyses of the experimentally obtained results for the stress on the bottom face sheet were carried out, Figure 4 . The analy- sis of the results summarized in Table 2 lead to conclusion that the deflections and ultimate tensile strength in the bottom face sheets in each series of sandwich panels are approximately equal when subjected to ultimate load. I case of equal load, the series of sandwich panels SE2R have minimal higher stress in the bottom face sheet in comparison to series sandwich panels SP2R, as can be seen in Figure 4. Nevertheless, it should be mentioned that the stresses in the composite face sheets are very small in comparison with the strength of the composite material, and the properties of the composite material are not completely used. 


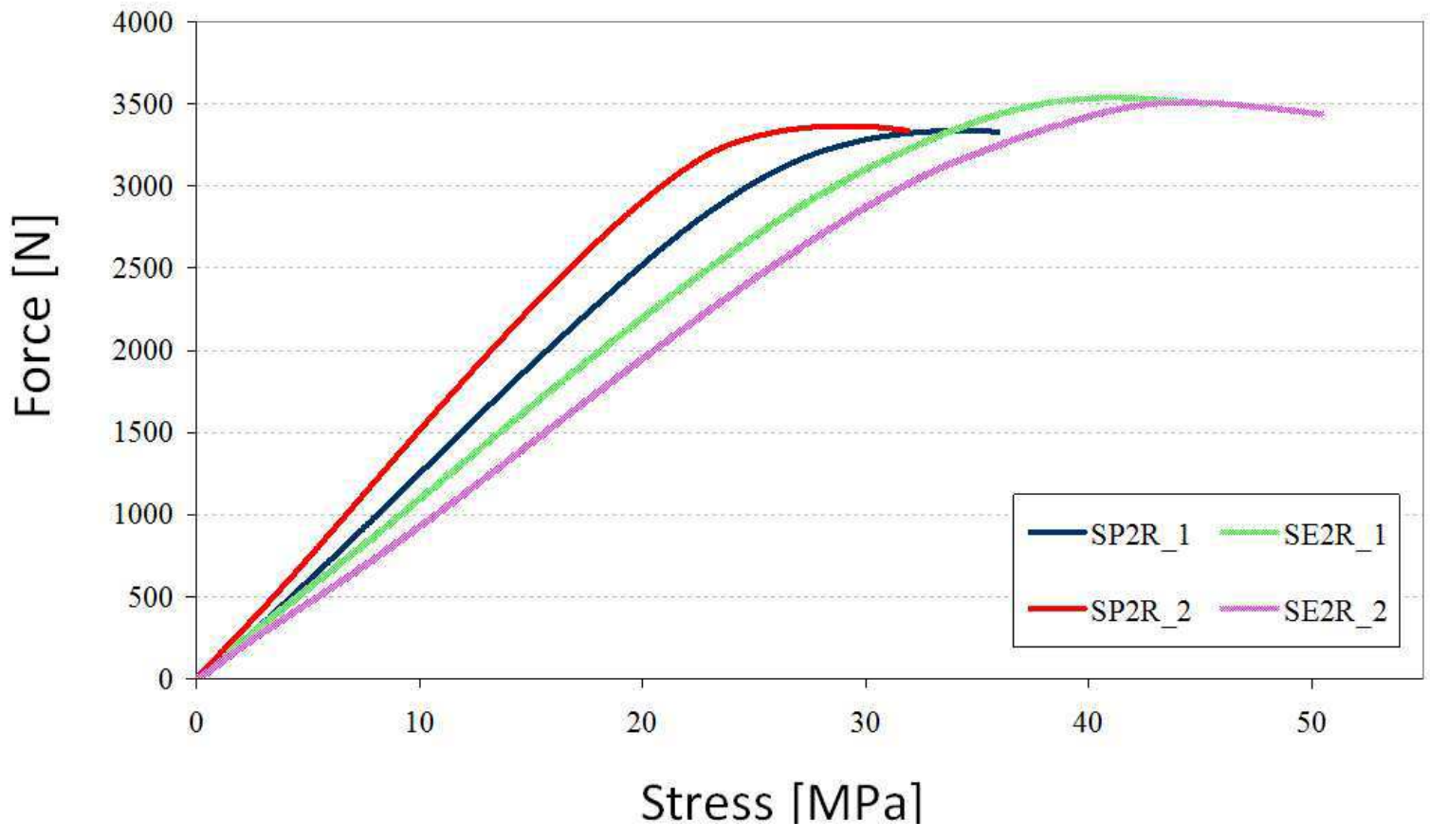

Figure 4: F- $\sigma$ diagrams for specimens $S P 2 R$ and $S E 2 R$ subjected on three point bending test

The results of the performed experiments state that the fracture of the sandwich panels was followed by fracture of the top composite face sheet and fracture of the polyurethane foam core in the top of the sandwich panels, while the bottom composite face sheets remained undamaged with no visible cracks, Figure 5.
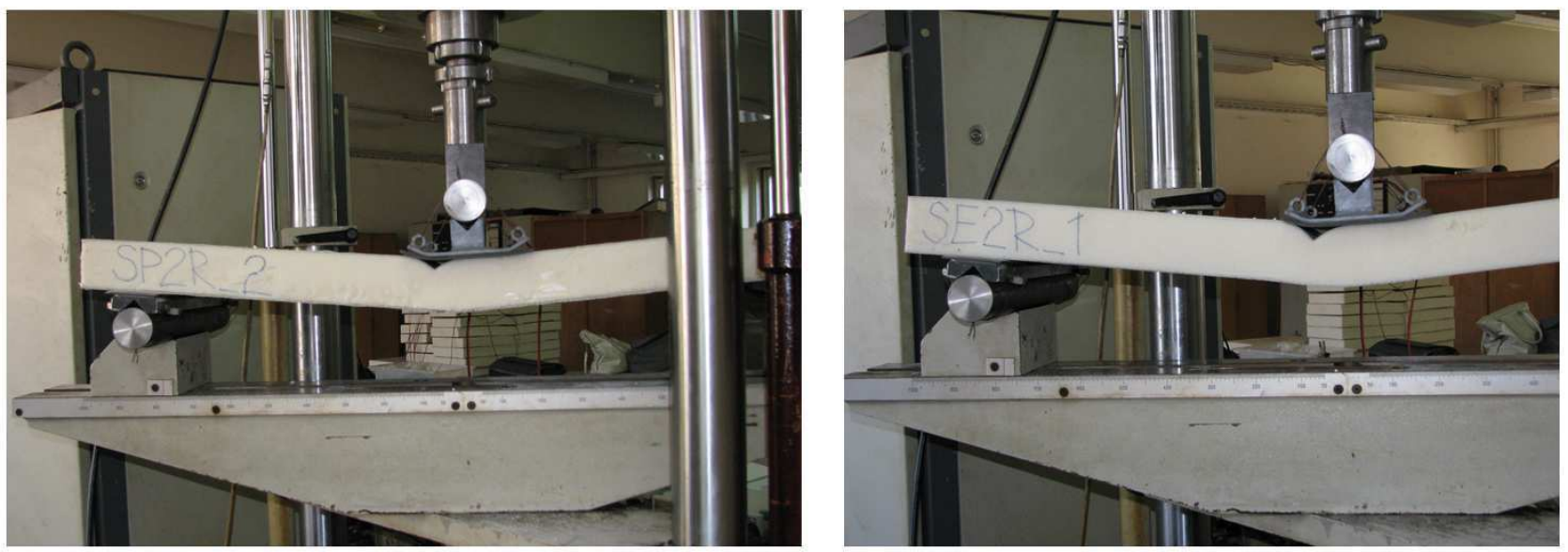

Figure 5: Fracture of the sandwich panels SP2R and SE2R subjected on three points bending test

\section{CONCLUSION}

This paper presents results from the experimental tests of two series of sandwich panels subjected on three points bending test. Analyzing the experimentally obtained results it can be concluded that the type of matrix used in the composite face sheets doesn't have a great influence on the initial strength of the sandwich panels and on their deformation. Similarly, the type of the matrix used in the composite face sheets doesn't have an influence on the stress in the bottom face sheet, on the stiffness of the sandwich panel and on their ultimate bearing capacity.

Experiments show that the fracture of the sandwich panels is driven by the characteristics of the polyurethane foam core. It's low strength and deformation characteristics have great influence on the fracture of the sandwich panels. It does not permit a utilization of the characteristics of the composite materials used for the face sheets. 


\section{REFERENCES}

1) A. Alias, N.A.A. Nor, M.R. Said: "The Behaviour of Square Sandwich Panel. Part I: Under Static Loading", Journal Teknologi, 47, 2007, 1-18

2) H.G. Allen: "Analysis and Design of Structural Sandwich Panels", Pergamon Press, Oxford, 1969

3) M.F. Ashby, L.J. Gibson: "Cellular SolidsStructure and Properties", Pergamon Press, Oxford, 1997.

4) Q.M. Li, R.A.W. Mines, R.S. Birch: "The Crush Behaviour of Rochacell-51 WF Structural Foam", International Journal of Solids and Structures, 37, 2000, 6321-6341

5) K. Lingaiah, B.G. Suryanarayana: "Strength and Stiffness of Sandwich Beams in Bending", Experimental Mechanics, 31, 1991, 1-7
6) R.A.W. Mines, A. Alias, Q.M. Li, R.S. Birch, J.A. Close: "On the Measurement of the Crush Behaviour of Structural Foams", 11th International Conference on Experimental Mechanics, 1998, 287-292

7) R.A.W. Mines, A. Alias: "Numerical Simulation of The Progressive Collapse of Polymer Composite Sandwich Beam under Static Loading", Composites: Part A, 33, 2002, 1126

8) F. Plantema: "Sandwich Construction, The bending and buckling of Sandwich Beams, Plates and Shells", John Wiley \& Sons inc., New York, 1966

9) S.R. Swanson, J. Kim: "Design of Sandwich Structure under Contact loading", Composite Structures, 59, 2003, 403-413

Paper sent to revision: 26.01.2016.

Paper ready for publication: 15.03.2016. 


\section{EKSPERIMENTALNO ISPITIVANJE KOMPOZITNIH SENDVIČ PLOČA SA RAZLIČITIM SPOLJAŠNIM PLOČAMA}

Ana Trombeva-Gavriloska, Univerzitet “Sv. Kiril i Metodij” Skoplje, Arhitektonski fakultet, Skoplje, Makedonija

Marijana Lazarevska, Univerzitet “Sv. Kiril i Metodij” Skoplje, Arhitektonski fakultet, Skoplje, Makedonija

Meri Cvetkovska, Univerzitet “Sv. Kiril i Metodij” Skoplje, Arhitektonski fakultet, Skoplje, Makedonija

U ovaj rad prezentirani su ekspeimentalni rezultati za dve serije sendvič panela sa spoljašnim kompozitnim pločama koje se razlikuju po upotrebljenoj matrici. Sendvič ploče ispitivane su prilaganjem linijskog opterećenja u sredini raspona. Analize su izvedene kako bi se ocenio uticaj tipa matrice na granične mehaničke karakteristike sendvič panela. Uticaj tipa matrice kompozitnih spoljašnih ploča je ocjenjen analizom F- $\delta$ ponasanja sendvič ploča, kako i $F-\sigma$ ponašanja kompozitnih ploča.

Ključne reči: Kompozitne sendvič ploče, Mehaničke karakteristike, Ekperimentalna ispitivanja 